IZA DP No. 7356

Ora et non Labora? A Test of the Impact of Religion on Female Labor Supply

Francesco Pastore

Simona Tenaglia

April 2013 


\title{
Ora et non Labora? A Test of the Impact of Religion on Female Labor Supply
}

\author{
Francesco Pastore \\ Seconda Università di Napoli, \\ IZA and AIEL \\ Simona Tenaglia \\ ISFOL
}
Discussion Paper No. 7356
April 2013

IZA

P.O. Box 7240

53072 Bonn

Germany

Phone: +49-228-3894-0

Fax: +49-228-3894-180

E-mail: iza@iza.org

Any opinions expressed here are those of the author(s) and not those of IZA. Research published in this series may include views on policy, but the institute itself takes no institutional policy positions. The IZA research network is committed to the IZA Guiding Principles of Research Integrity.

The Institute for the Study of Labor (IZA) in Bonn is a local and virtual international research center and a place of communication between science, politics and business. IZA is an independent nonprofit organization supported by Deutsche Post Foundation. The center is associated with the University of Bonn and offers a stimulating research environment through its international network, workshops and conferences, data service, project support, research visits and doctoral program. IZA engages in (i) original and internationally competitive research in all fields of labor economics, (ii) development of policy concepts, and (iii) dissemination of research results and concepts to the interested public.

IZA Discussion Papers often represent preliminary work and are circulated to encourage discussion. Citation of such a paper should account for its provisional character. A revised version may be available directly from the author. 


\section{ABSTRACT \\ Ora et non Labora? \\ A Test of the Impact of Religion on Female Labor Supply}

This paper examines the influence of religion on female participation to the labor market using data relative to women aged between 18 and 60 years in 47 European countries drawn from the European Values Study (EVS). We investigate the determinants of the probability of being employed rather than jobless in a LOGIT framework. The results show that women belonging to the Orthodox and, even more, Muslim denominations present a higher risk of non-employment than the agnostics, while being a Protestant increases the probability for a woman to be employed. Although its intensity is slightly weakening, the association between religious affiliation and female labor supply is robust to different sets of controls for individual and household heterogeneity as well as for welfare regimes and country specificities. Once disentangling religiously active and non-active women, we find that there are small differences between them in the case of the Orthodox and Muslim women, while active Catholic women tend to work less and non-active Protestant women tend to work more than average.

JEL Classification: D1, H75, J13, J16, J22, N30, Z12

Keywords: female labor supply, religion, welfare state regimes, child care

Corresponding author:

Francesco Pastore

Seconda Università di Napoli

via Mazzocchi 5

Santa Maria Capua Vetere (CE)

81055 Naples

Italy

E-mail: fpastore@unina.it

\footnotetext{
* This paper has been presented at seminars at the World Interfaith Harmony Week, Seconda Università di Napoli (22-24 March 2012), the XXVII AIEL Conference (27-28 September 2012) and the $53^{\text {rd }}$ Annual Conference of the Italian Economic Society (18-20 October 2012). We thank all seminar participants and especially Tindara Addabbo, Francine Blau, Maria Rosaria Carillo, Justina Fischer, Lawrence Kahn, Peter Nijkamp and Annie Tubadji for valuable comments. Nonetheless, the usual disclaimer applies.
} 


\section{Introduction}

Economists are generally reluctant to admit the influence of cultural, and, in particular, religious beliefs on the economic behavior of individuals. This moves away economists from the common sense, while bringing their theories at odds with the "orthodoxy", so to say, of other social sciences and also the facts of real life. News stories are full of examples among which to choose. Large anecdotal evidence suggests that the female behavior in life and specifically in the labor market is dramatically affected by their religious beliefs, by the religious beliefs of their parents and their husbands. On the one hand, a common accusation of EU citizens on immigrants, for instance, or on the countries belonging to the neighboring region of North Africa, is that their religion might be seen as an obstacle on the way to integration with the EU and to the path that should lead to democracy. The attitude of the Muslim religion on women' work is often mentioned as evidence of this. On the other hand, women in the Nordic Protestant countries often seem to believe that their pairs in the Southern Catholic and Orthodox countries are impeded to work by their religious beliefs.

Is there statistical evidence to support these claims? We find an astonishingly neat negative association between the share of individuals belonging to the catholic (and orthodox) religion in the population of European countries and that of active women in the labor market. Is this unconditional relationship robust to controls for individual and environmental heterogeneity? What is the role of childbearing policy and how is itself affected by religious beliefs?

This study examines the influence of religion on women's decision to enter the labor market in a cross-country dimension by using data from the European Values Study (EVS) relative to 47 European countries. We use a LOGIT framework to understand the determinants of being employed rather than jobless and focus on women aged between 18 and 60 years. The results show that women belonging to the Orthodox and, even more, Muslim denomination present a higher risk of non-employment than the agnostics, while being a Protestant increases the probability for a woman to be employed. Although its intensity is slightly weakening, the association between religious affiliation and female labor supply is robust to different sets of controls, such as a number of individual, household and demographic characteristics as well as the type of welfare regimes and country specificities. 
The main novelties of this paper are as follows. First, while several recent studies have been focusing on the role of religion on cultural beliefs about some aspects of the economic and social life and such events as maternity (see the seminal contribution of Guiso et al. 2003), this is the first paper to focus on the impact of religion on female labor market participation in a cross-country perspective. Previous analyses of the impact of religious principles on female participation related to a single nation (Heineck 2004, Maneschiold and Haraldsonn 2007, Bau and Kahn 2012). The specific nature of the European countries considered, which is quite homogeneous from a geographical, historical and political point of view, allows us to look more specifically at the role of religious denominations. In the meantime, a large literature suggests that European countries belong to several well identified macro clusters of welfare state regimes which should allow further reducing the degree of heterogeneity in the data, therefore contributing to identify the actual impact of different religious affiliations on the probability of women to participate to the labor market. Moreover, the EVS allows us distinguishing between individuals who actively participate to religious life from the rest, by using a wealth of different definitions of being religiously active, such as: a) frequency of attendance of religious services; b) self-reported declaration of the extent to which the respondents feels to believe in god; c) the extent to which god is important in the respondent's life; d) the time destined to prayer; e) how often the respondent prays outside of religious places. Last but not least, our database allows identifying natives and immigrants of first and of second generation to take into account the possible impact of assimilation.

The outline of this paper is as follows. Section one motivates the paper by showing its starting hypothesis and by discussing its relevance. Section two surveys the existing literature on the link between religious beliefs and female labor market participation. Section three discusses the methodology adopted in this study. Section four introduces several features of the data used to carry out the econometric analysis. Section five presents the results of the econometric analysis. Some concluding remarks follow.

\section{Motivation}

In all EU27 countries, there is a gender gap in employment rates, with the only exception of Latvia and Lithuania where gender differences are irrelevant. The EU27 average female to male employment ratio equals $83 \%$ in 2010 , as based on Eurostat data. Only in Denmark, Finland and Sweden the ratio is between $90 \%$ and $98.5 \%$. Thirteen out of twenty-seven nations 
show female employment rates that are lower than male employment rates by between 10 and 20 percentage points. There is also a group of Mediterranean countries where the difference between the two rates is much higher, reaching $48 \%$ in the case of Malta and $32 \%$ in the case of Italy and Greece.

Apparently related to this evidence is that relative to the share of individuals that declare to belong to the Catholic and Orthodox (in the case of Romania, Bulgaria, Cyprus, Estonia and Greece) denominations, as they result from the questions asked in the European Values Survey. Figure 1 shows how in countries with higher Catholic or Orthodox presence there is less participation of women in the labor market. Italy, Greece, Poland, Romania and Hungary are part of this group. By contrast, in countries with shares of Catholics lower than $40 \%$, the female participation rates reach values between 65\% and 75\% (Denmark, United Kingdom, Finland and Sweden).

\section{[Figure 1 about here]}

Obviously, religion is just one among many factors that influence women's participation in the labor market, and it cannot be hence satisfactory just to compare mean values. High rates of female participation of European Catholic countries, like Austria for example, are also due to different welfare state traditions that result in policies promoting the female participation rate. It's worth noting that in many countries work gives access to a range of social rights that people would otherwise lose, such as welfare and health rights.

However, the negative relationship between religious denominations and female participation rates is so clear and strong that we naturally wonder if the statistical association reveals the possible existence of a causal link between the phenomena of female labor market participation and belonging to one or another denomination. Our goal is to carry out a crosscountry analysis to assess the extent to which religion explains the low participation rates of women in the labor market. We also ask ourselves if, in addition to the policy factors, also cultural and religious specificities of a nation are able to explain not only the low female participation in the labor market. In fact, by influencing individual attitudes and behaviors, cultural and religious values necessarily have a role also in the formation of women's career choices. Undoubtedly, the entry of women into the labor market depends also on men's attitude towards female work. Such men's attitude has an effect on decisions that are taken within the family. In this sense, male religious values have a role in determining the female participation rate. 
We base our hypothesis on the division of roles proposed by the social Catholic doctrine. In the Apostolic Letter Mulieris Dignitatem the Catholic doctrine reaffirms full equality between men and women within marriage. However, women are considered to be the most suitable to the roles of care and to reproduction activities which must take precedence over other forms of employment. Pope John Paul II was one of the strongest supporters of this argument, pointing out to the specific "feminine genius" in performing caring roles.

If these are the premises, one may wonder whether a significant percentage of women, that were educated on the basis of these values, can reject the idea of seeking work, not to mention the ambition to be business leaders or politicians.

Moreover, even if the argument proposed by Guiso et al. (2003) - who note that "...religious teaching do not necessarily reflect the authentic message contained in the sacred texts. They simply represent the way certain religious beliefs became crystallized over time..." - is to be fully shared, nevertheless it is reasonable to think that the effect of religious teaching on women economic decision to enter the labor market might possibly be still detrimental, after all.

Last but not least, we aim to understand whether the catholic and orthodox faiths have a greater or smaller impact than others, such as the Muslim, Jewish, Evangelical, Hindu and so on. To such an end, we compare the labor market behavior of women belonging to different denominations. In fact, the data set used provides information not only on the European Union, but on Europe at large, which allows us considering the role also of other religions but the catholic and orthodox.

In other words, we aim to understand the influence of religion in general on women's decision to enter the labor market, controlling for a number of socio-demographic, economic and cultural factors. In the doctrines of all religious denominations, women are considered to be particularly good in performing care activities. One could say that they are assigned a sort of "competitive advantage" in childcare and other reproductive activities, while having a "competitive disadvantage" in productive activities. Therefore, they must give priority to work within, rather than outside the family. The consequence of this division of roles is that women educated on the basis of religious values may reject the idea of entering the labor market, not to mention the ambition of being managers or leaders of political parties. According to the way different religious doctrines have been formulated, the effect on women may be possibly different. 
Also based on the survey of the literature contained in the next section, the questions to ask are many. Is there any difference among religious denominations in the way of conceiving female productive labor? Which religion is less favorable to women' work? Which is more? Is it religion itself or the level of development the country has reached that matters? What is the role of secularization? Is it the fact itself of belonging to a given religious denomination that matters or how actively women (and/or their family members) attend religious activities or accept religious dogma? What is the influence of religion vis à vis other cultural, social and political factors? Considering that religions tend to shape the welfare system, is it the type of childbearing policy implemented in a country that matters or religion itself?

\section{The state of the art}

The recent literature, and not just the economic one, is investigating on the relationship between female participation rates, on the one hand, and cultural and religious values, on the other hand.

Several studies show how different cultures and institutional structures affect the formation of individual attitudes and behaviors. Inglehart and Norris (2003), for example, argue that the process of modernization has produced increasing gender equality. In particular the shift from agricultural societies, which reflect traditional values, to post-industrial societies has generated more egalitarian attitudes. According to the authors, during the modernization process, it is not income anymore to ensure gender equality, but the cultural change and the adaptation of religious values. Another important factor is represented by the role of the state through the promotion of women's agency and social rights. Heather Antecol (2003) analyzes the determinants of female participation rates in Europe, Middle East, Asia, Oceania and North America, using the International Social Survey Program (ISSP) dataset. Cultural aspects are taken into account through proxies that measure men's attitude towards family and the distribution of gender roles. The results show that it is more likely that women enter the labor market when their partners agree with their choice.

Fernández and Fogli (2009) investigated the influence of culture on married women's work behavior, using a sample of women born in the USA but whose parents were born elsewhere. They found a positive and significant effect of cultural factors on women's work behavior even after controlling for individual and spousal characteristics. 
In a research about Chile, a country with a rooted Catholic tradition, Contreras and Plaza (2010) tested the hypothesis that in the short term cultural attitudes influence women's participation rate. In particular, more conservative women participate less to the labor market.

It is worth underlining that in this type of analysis there is a problem of causality direction, so that the results presented by the authors have a value of short-term effect or just association between variables. If on the one hand it is possible that cultural attitudes determine female participation in the labor market, on the other hand it is well plausible also that women's participation in the labor market influence their cultural norms.

Stephanie Seguino (2007) shows that the entry of women into the labor market has produced an effect on social norms and stereotypes, albeit with a lag of five years. This time is necessary for women in order to perceive a change in their status.

Another difficulty of these studies is trying to separate out cultural and religious values. However, there are some works that analyze the effects that religion produces on women's decision to enter the labor market. Esping-Andersen (1990) analyses how religious denominations are likely to influence the employment patterns by shaping subjective values. He classifies nations into social-democratic, liberal and conservative-corporatist countries and associates the latter with the Catholic countries in Continental and Mediterranean Europe. His conclusion is that conservative-corporatism promotes the male breadwinner conception by implementing welfare and family rights detrimental to women labor market participation. However, Esping-Andersen does not provide quantitative evidence.

Some recent microeconomic works have focused on the influence exerted by religion on several aspects of life and not least on such economic and social choices as participation to the labor market. These studies argue that formal religious institutions exert a strong influence, through the definition of social norms and behaviors, on the division of roles between men and women (Inglehart and Norris, 2003).

Guiso et al. (2003) use three waves of the World Values Survey (1981-4, 1990-3 and 19957). Respondents come from 66 independent countries. These countries include almost 80 percent of the world's population. The authors focus on questions that might influence women's propensity to work. Their dependent variables are answers to a variety of questions ranging from: 1) Who should get a job first, a man or a woman, when jobs are scarce?; 2) Who should have priority in obtaining university education within the household, a men or a women?; 3) Who should contribute more to household income, a men or a women? They run OLS regressions analysis controlling for demographic characteristics (health status, male, age, 
education, social class, income), and several indicators of religiosity. They find that the lower tolerance of individuals most involved in religious activities towards women's work is not a specific attribute of Catholicism or Islam, but is widespread across many religions, including Protestantism. This result would seem to comfort the conclusions reached by Knudsen and Waerness (1999), who claim that women's participation in the labor market is rather the consequence of the secularization process, which has led to different attitudes and behaviors in Western industrialized countries. In particular, two major components of this process would be represented by the struggle for gender equality and the process of women personal growth.

In a later work, Knudsen and Waerness (2001) construct an indicator that summarizes the attitude towards gender roles and mothers' work using ISSP (International Social Survey Programme) data. The result obtained is that people who attend religious places with more diligence and study the doctrine show a less liberal attitude. The work of Sjoberg (2004) confirms this result: individuals with less liberal attitudes are those who more frequently attend religious services and study the doctrine. The author uses multilevel regression techniques on data from the 1994 ISSP module 'Family and Changing Gender Roles II', relative to 13 industrialized countries. Dependent variable in the estimated models is the "Attitudes towards female labor force participation Index", that includes five items on which respondents have been asked to indicate their degree of agreement or disagreement: 1) "A preschool child is likely to suffer if his or her mother works"; 2) "All in all, family life suffers when the woman has a full-time job"; 3) "Being a housewife is just as fulfilling as working for pay"; 4) "A man's job is to earn money; a women's job is to look after the home and family"; 5) "It is not good if the man stays at home and cares for the children and the woman goes out to work". Dependent variables are sex, age, level of education, religiosity combined with religious belonging. These variables have the expected sign: women have a significantly higher coefficient than men; the level of educational attainment has a significantly positive effect; and age has a significantly negative effect. What matters more is the attendance of religious services, rather than belonging to a religious denomination itself.

$\mathrm{H}^{\prime}$ madoun (2010) presents an empirical analysis of the influence of religiosity on women's decision to enter the labor market. The author employs the 2005 wave of the World Value Survey to check whether the decision of women aged 18 to 55 to work is influenced by individual religiosity. $\mathrm{H}^{\prime}$ madoun estimates a labor force participation equation by employing a probit technique, given that the dependent variable equals 1 if individuals are in full-time / 
part-time jobs or self-employed, and 0 for other conditions. In addition to the usual dependent variables (age, education, marital status, health and children), the author introduces religious variables such as religious affiliation, intensity of belief and attendance of religious services. The analysis confirms the hypothesis of a significant difference between religious and nonreligious female decisions see employment: religious women enter the labor market less than non-religious women. Taking as reference category nonaffiliated women, almost all religious affiliations have a negative impact on female participation. Moreover, as individual's intensity of beliefs increases, the likelihood of employment decreases, confirming that what matters more is religiosity rather than the religious affiliation itself (Iannaccone 1998).

Heinek (2004) analyses decisions of married women to divide their time between the participation in the labor market and non-market activities. The author uses data drawn from the German Socio-Economic Panel (GSOEP), providing information on all household members. The author estimates a multinomial LOGIT model, where the dependent variable is the employment status of married women in Germany in 1997 (full-time employment, part-time employment, not employed), while the independent variables are age, years of education, children up to age of 6 and children aged 7 through 16, health status, religious affiliation combined with religiosity level, residence's municipal size. The main result is that married women's decisions are influenced by both the role division prescribed by their religion and their level of religiosity. The same result is obtained by Maneschiold and Haraldsson (2007), who uses data drawn from the Swedish Level of living Survey (LNU), selecting only married women. They use a multinomial LOGIT framework, where the employment status of married women represent the dependent variable, while controlling for family and individual background (age, education, age of children, health, main responsibility for the household, size of the city where the woman is living) and the importance women attach to a religious faith who is very strict towards female labor participation. The authors find that married women who belong to a religious denomination which is very strict towards female work tend to participate less in the labor market with respect to married women who are less strict in their religious convictions.

Few analyses focus on the differences among religious denominations and the results are not homogeneous: while the work of Gomilshack et al (2000) show greater aversion to the work of Catholic women, Sjoberg (2004) argues that the Catholic and Protestant doctrines in part share the same vision of the traditional roles in family. This can be explained thanks to the political institutionalization of religious values and traditions within the party system in some 
Protestant countries such as Norway and the United States. By paying particular attention in teaching women's care obligations, Catholicism, however, yields a more traditional distribution of roles. Interestingly, Blau and Kahn (2012) find a negative effect of belonging to a religious denomination on the labor supply of women who migrated to the United States with respect to the omitted category of no religion, but controlling for religion did not affect the main results of the paper for pre-migration and source country female labor supply.

Another aspect considered in the literature is the influence religious denominations have on the development of laws and national institutions (Algan and Gauch, 2006). If in a nation there is a common notion that man is the family breadwinner, probably the policies will reflect this concept. Italy is among the countries belonging to the Latin Rim in which the household is the main provider of welfare services and in which the emancipation of family members takes place "within", rather than "from" the family (Bettio and Villa, 1998). Women have to take care of their children, parents and the disabled family member during all their life cycle. Policies that encourage the creation of a market for occupations related to care services (such as in-kind services or tied cash transfers) would undoubtedly produce positive effects on women labor market participation.

\section{Methodology}

Following a standard approach in the literature, we estimate the following labor force participation equation:

$$
F P_{i}=\beta_{0}+\sum_{i=1}^{n} \beta_{i} X_{i}+\sum_{j=1}^{8} \gamma_{j} R_{j}+\sum_{m=1}^{9} \delta_{m} W_{m}
$$

whereas the dependent variables is a binary choice outcome:

$$
F P_{i}\left\{\begin{array}{c}
1 \text { if the woman is employed } \\
0 \quad \text { if the woman is non-employed }
\end{array}\right\}
$$

$F P_{i}$ is the $i_{\text {th }}$ individual's employment status, including wage employment, permanent or temporary, full-time or part-time, and self-employment. We group in non-employment both the unemployed and the inactive individuals.

$X_{i}$ is a vector of socio-demographic variables that are expected to influence labor supply. We think of three groups of control variables: individual variables, household variables, migration status, social status and, so to say, social variables. The individual and household level variables include age, educational attainment, marital status, the overall number of 
children, having one or more children under the age of 10 years, co-residence of parents and grandparents in the household.

To catch the migration status, first of all, we distinguish among natives, immigrants of first generation and immigrants of second generation, based on the place of birth of parents. Both parents of a native were born in the country. An immigrant of first generation is resident in the given country, but was born abroad. An immigrant of second generation was born in the country from foreign parents. We also control for the case of individuals with at least one parent (father or mother) who was born abroad and individuals with a foreign partner.

Information on some important household characteristics should allow controlling for the possibility, ventilated in the literature, that the influence of religion might pass through the educational, social and economic background of the family in which the individual is living. We expect that women living in a family holding a high standard of living or with a high educational background are less affected by religious prescriptions than their pairs living in poor families. To such an end, we then control for the case of women living in a family whose income is below the poverty line. We also control for parents' educational background.

To control for the level of development / degree of secularization of religion, we adopt different strategies. First of all, we use the population size of the place of residence to distinguish urban from rural areas, where the impact of religion might itself mix up with that of a different level of social development. In addition, we use the educational level of parents to catch the educational background of individuals and their social status. The social status of respondents is also expectedly caught by the fact of living under the poverty line.

Equation [1] also includes a set of $\mathrm{W}_{m}$ variables that describe the welfare state regimes of each country. The childbearing policy might affect female labor supply decisions. It may be that women seek employment in some countries less than in others because of the welfare regime existing in the country. Although the religious denomination variables are defined individually, it is clear that the countries characteristics matter, since in most European countries there is one prevailing religion. First, we use a vector $W_{i}$ of 9 dummy variables, each one representing a group of homogeneous countries for the type of welfare state organization and management. Second, in some of the estimates, as an alternative, we use a variable measuring the country level of per capita social expenditure. In other specifications, we use country dummies.

The religious variables are included in $R_{i}$. As better detailed in the data section and in Table A1 in the Appendix, the data allows distinguishing 9 religious denominations, which have 
been grouped in 6 because of the small cells relative to some denominations (Jewish, Hindu, Buddhists and others), plus the agnostics and the atheists, used in the estimates as baseline. In addition, in some specifications, to take into account the importance of active participation to religious life, two separate dummy variables are included for each religious denomination, of which the former regards active participation. Third, for each religion, we have separate dummies for natives, first generation immigrants and second generation immigrants.

Since the dependent variable is a binary outcome, we estimate the following probability by LOGIT:

$$
\begin{array}{r}
\operatorname{Pr}\left(F P=1 \mid \sum_{i=1}^{n} X_{i}+\sum_{j=1}^{8} R_{j}+\sum_{m=1}^{9} W_{m}\right)= \\
=\frac{e^{\beta_{0}+\sum_{i=1}^{n} \beta_{i} X_{i}+\sum_{j=1}^{8} \gamma_{j} R_{j}+\sum_{m=1}^{9} \delta_{m} W_{m}}}{1+e^{\beta_{0}+\sum_{i=1}^{n} \beta_{i} X_{i}+\sum_{j=1}^{8} \gamma_{j} R_{j}+\sum_{m=1}^{9} \delta_{m} W_{m}}}
\end{array}
$$

\section{Data}

Our empirical analysis is based on the EVS, a large-scale, cross-national and longitudinal dataset on basic human values. It provides insights into the ideas, beliefs, preferences, attitudes, values and opinions of European citizens. The available variables are related to the following dimensions of life: Perceptions of Life; Politics and Society; Work; Religion and Morale; Family; National Identity; Environment; Life experiences; Respondent's parents; Respondent's partner Socio Demographics Characteristics ${ }^{1}$. We use the fourth wave relative to 2008 that covers 47 European countries/regions. The sample is composed by almost 68000 individuals, of which 36800 are women. Table A1 in the Annex provides all the details relative to the variables' definition, showing for each variable the name and definition as based on the EVS.

Our sample is represented by women aged between 18 and 60 years. The question corresponding to the female labor force participation variable (employed_notemployed) is the following one: "Are you yourself employed or not?". We codify it as a dichotomous variable that takes value 1 if the interviewed is employed, and value 0 if she is not employed, like in H'madoun (2010).

\footnotetext{
1 For a description of all the available variables, see: http://zacat.gesis.org/webview/index.jsp?object=http://zacat.gesis.org/obj/fCatalog/Catalog5.
} 
Age is calculated by using the year of birth of respondents. Age squared tests for the existence of a $\mathrm{U}$-shaped effect. Five dummy variables measure the level of education of respondents, as based on the ISCED classification, and the expected effect is that the higher is the level of education, the higher is also the level of participation.

We group together women who are married or involved into a registered partnership, the baseline being constituted by single women. We expect that a woman legal status should help understanding the different female behavior when women have to allocate their time among home domestic production, work outside the family and leisure time. Moreover, it should help appreciating the influence of the division of roles and of the husband preferences when women live in a household.

We then consider the presence of parents and grandparents in the household. Expected coefficients are not unambiguous, because parents and grandparents that live in the household may have a double effect on female labor force participation: if they are in good health, they can help with both children care and household management, facilitating the work of women. On the contrary, if they are not in good health and need assistance themselves, women may decide not to enter (or not to re-enter after giving birth) the labor market to carry out care activities within the household. Since in our data it is not possible to assess the health status of parents and grandparents, the relation between the presence of parents and grandparents in the household and women's labor supply cannot be predicted $a$ priori.

The presence of children in the household and, in particular, of a first child under the age of 10 years is expected to be another important factor able to affect a woman' decision to enter the labor market.

The variable "Being under the poverty line (poors_Az1)" is a dichotomous one that equals 1 if the household income is lower than the poverty threshold, and 0 if it is higher ${ }^{2}$. We expect that poorer households tend to be more traditional and therefore more strongly affected by religious principles.

We consider different definitions of belonging to a religious denomination, of which two are the most important: i) religious belonging; ii) religiosity. The EVS allows different definitions of religiosity: a) frequency of attendance of religious services; b) self-reported declaration of the extent to which the respondents feels to believe in god; c) the extent to which god is important in the respondent's life; d) the time destined to prayer; e) how often

\footnotetext{
${ }^{2}$ The poverty line is defined having a household income below $2 / 3$ of the median income in the data .
} 
the respondent prays outside of religious places. In what follows, for shortness' sake, we focus on the first two definitions.

As noted before, religions can influence women's decision to work through the support provided to a specific division of gender roles, where women are the ones with primary responsibility for the care of children and the family (Fortin, 2005). Other than the religious affiliation, an important aspect is represented by the religious capital accumulated through the attendance of religious services. The more respondents are involved in religious activities, the more they are exposed to religious precepts (Heinek 2004), the higher is the influence of religious doctrines on their preferences and decisions in life. To take this into account, for each religious denomination, we define a group of active believers and a group of non-active believers.

Moreover, following the definition given by, among others, Simonazzi (2008), in order to control for different welfare state regimes, we divided the 47 nations included in the EVS databank in eight groups: Scandinavian, Mediterranean, Central European, Anglo-Saxon, East European, which have been further subdivided in countries that entered the EU in 2004 and countries that entered the EU after 2004, former-Yugoslavian, former Soviet Union republics, and, finally, Turkey and North Cyprus.

A last control is for country fixed effects. H'madoun (2010) underlines how the introduction of country dummies determines an underestimation of the effect of religion given that the national culture also capture religion. The hypothesis we wish to test with this type of specification is exactly whether there is some specificity attached to religious beliefs that persists also after controlling for other national specificities, in addition to individual, environmental and cultural factors.

Last but not least, we control for the nationality of the interviewee and her migration status. We distinguish between natives, immigrants of first generation and immigrants of second generation. Furthermore, we generate dummies to identify the religion to which each group belongs to, by interacting religious affiliation and migration status. This should allow catching the impact of assimilation on religious prescriptions and their impact on female labor supply.

A dummy that captures whether at least one parent, or both, are foreigners is included in the estimates to control for parents' nationality. A dummy variable to describe the nationality of the spouse or partner, that we think can influence the decision of a woman to enter the labor market, is also included in the estimates as a further control. 
Table A2 in the Annex reports the means of all the variables used in our regression analysis for the sample of women aged between 18 and 60 years. Table A3 shows the means of all the variables by religious denomination.

\section{Results}

\subsection{Unconditional gap}

Table 1 displays the cross tabulation of religious denominations and the employment / non-employment variable. The last two rows regard the agnostics. It shows a large variation in female employment rates by religious denomination. Most religions perform worse than the average and of the agnostics in particular. Muslim women seem to be those with the lowest average employment probability (32.3\%), followed by the Hindu (40\%), Jewish (53.9\%) and Orthodox (54.1\%) women. Catholic and Buddhist women have a slightly higher participation, at about $65 \%$. Protestant women are outstanding, at about $80.1 \%$.

\section{[Table 1 about here]}

Table 2 reports the results of unconditional LOGIT estimates of the employment probability by religious denomination. It confirms the finding of the previous table, while allowing us also computing the odds ratio with respect to the agnostics, representing the baseline. Muslim women have about $80 \%$ lower probability than the agnostics to find employment. Orthodox women about $50 \%$ and the other religions about $40 \%$. Catholic women tend to have about $25 \%$ less employment chances, which, quite surprisingly, is not far away from the atheists. Protestant women have $70 \%$ higher probability of being employed than the baseline.

\section{[Table 2 about here]}

What is the position of women relative to men? Looking at the relative disadvantage of women with respect to men in terms of employment probabilities might be important to understand whether their disadvantage is due to discrimination or, rather, to some country specific factor, as it is the case of the absolute disadvantage. In other words, the absolute employment rate might reflect the employment opportunities available to anyone in the country, whereas the ratio of the female to male employment rate might be a sign of factors that affect especially women. Figure 2 reports the relative female disadvantage in employment probabilities by religious denomination. It shows that all women, but the Jew ones, have a relative disadvantage with respect to men, as they lie below the bisector. Jew men and women have exactly the same employment chances. All the other religions seem to have the same 
relative disadvantage in favor of men, as their dot lies below the bisector at roughly the same distance from the bisector. It suggests that discrimination factors are similar across these religious denominations and the relative position of women in each religion in comparison with the others is affected by some external factors, such as the level of development of the areas where the religion is practiced. In other words, the fact that Catholic women have more employment chances than, say, the Orthodox, depends on the fact that Catholicism is practiced in countries where typically employment is higher.

Hindu and Muslim women are the exception. They lie much below the bisector: the data show, in fact, that they have an unconditional probability of employment that is half that of men.

[Figure 2 about here]

\subsection{Conditional estimates}

Table 3 presents results of different LOGIT models of the determinants of female labor supply, as based on equation [1]. These are our baseline estimates to which the following estimates will be compared, and, in fact, the simple declaration to belong to a given religious denomination is used in this specification to catch the impact of religion. We start from introducing only demographic and individual characteristics (Model A). In Model B we add also the simplest version of the religious variables. Model $\mathrm{C}$ augments the previous model by including also the total expenditure on social policy. In Model D, we control not only for percapita social expenditure, but also for different welfare state regimes, to see whether the impact of religious beliefs on female participation is influenced by the type of welfare regime adopted in the country. Model E presents the same estimates as in Model C, but including country dummies. For ease of interpretation, it is worth mentioning that the table reports odds ratios of the independent variables ${ }^{3}$, rather than estimated coefficients.

Turning first to the results of Model A, the probability of female participation in the labor market increases with age, but the effect is concave, since the coefficient of the squared term

\footnotetext{
${ }^{3}$ The odds ratio is the ratio of the odds of an event occurring in one group to the odds of it occurring in another group. The term is also used to refer to sample-based estimates of this ratio. These groups might be men and women, an experimental group and a control group, or any other dichotomous classification. If the probabilities of the event in each of the groups are $p_{1}$ (first group) and $p_{2}$ (second group), then the odds ratio is:

$\frac{p_{1} /\left(1-p_{1}\right)}{p_{2} /\left(1-p_{2}\right)}=\frac{p_{1} / q_{1}}{p_{2} / q_{2}}=\frac{p_{1} q_{2}}{p_{2} q_{1}}$,

where $q_{x}=1-p_{x}$. An odds ratio of 1 indicates that the condition or event under study is equally likely to occur in both groups. An odds ratio greater than 1 indicates that the condition or event is more likely to occur in the first group. And an odds ratio less than 1 indicates that the condition or event is less likely to occur in the first group.
} 
is negative and statistically significant. It means that the probability of being employed increases but with degreasing returns the closer women get to the retirement age. The estimates confirm the typical inversely U-shaped pattern commonly found also in other papers (Lehrer 1995, Heineck 2004).

Women who have completed compulsory school are more likely to be employed with respect to women who have only primary education or no education. Employment chances go up with the level of education going up. Interestingly, there is an upsurge related to tertiary education, whose coefficient goes up more than proportionally with respect to lower educational qualifications.

Ceteris paribus having children reduces the probability of employment. The presence of a first child under the age of 10 years further reduces the probability of finding employment, by between 25 and $30 \%$.

Being married or in a registered partnership reduces the probability to be employed by about $8 \%$ with respect to being a single, although the impact becomes statistically insignificant when adding controls for religion and social expenditure.

Having parents living in the households, and also grandparents, although to a lesser extent, increases the employment probability of women. This may be due to the help women receive from their parents, especially when children are young.

Turning to the economic conditions, women who are under the poverty threshold present a much higher risk to be unemployed / inactive, by about a half. This can be explained given the deprivation condition that features individuals living under the poverty line, not only in terms of income and consumption, but also in terms of social networks, levels of education, financial exclusion etc. All these factors make it harder looking for a job and, even more so, finding a job.

The migration status matters only among immigrants of the first generation: in fact, they experience a ceteris paribus lower probability of employment than the natives, by 25 probability points. Immigrants of second generation appear already to be assimilated to the natives: although negative, and not far away from the coefficient of first immigrants, in fact, the coefficient is not statistically significant. This might suggest that there is important heterogeneity among the immigrants of second generation. The fact of having one parent or a partner who is immigrant does not make a statistically significant difference.

Parental educational background, instead, seems to be strongly correlated to employment chances, although the impact is not statistically significant when we add other control 
variables, but for some educational qualification. Strangely enough, the impact of parental education tends to reduce with education increasing, but this is likely to depend on the strong correlation existing among the educational level of parents and their children.

The same conclusion applies to the population size of the place of residence. Although statistically significant in some specification, the coefficient is very close to zero.

As expected, the per capita social expenditure has a positive impact on female labor supply decisions, since it yields a greater supply of social services, including maternity services.

These results are confirmed for all regressions in Table 1, independent of the other regressor added to the basic specification.

Model B includes also controls for religious affiliation and the odds ratios seem to confirm some of the theoretical expectations, although interestingly some of the unconditional gaps among religions tend to already disappear at this stage. Women belonging to the Orthodox and, even more so, the Muslim denomination present a ceteris paribus higher risk of nonemployment than the agnostics, while, interestingly, being a Protestant increases the probability for a woman to be employed. Orthodox and Muslim women have about $40 \%$ and about $62 \%$ less chances than the agnostic to be employed. Protestant women, instead, have ceteris paribus about $60 \%$ more chances of employment than agnostic women.

The women who belong to other denominations (Catholics, Jew, Buddhist, Hindu, others) have the same employment chances as the baseline group of the agnostics. More specifically, Catholic women have about $6 \%$ lower chances of finding employment than an agnostic woman, but the difference is not statistically significant. This finding is already rather surprising, considering the unconditional result reported above and the evidence contained in Figure 1. Just adding individual characteristics to the group of control variables importantly reduces the impact of religion on the employment probability. In other words, Catholic women have characteristics, in terms of age, education and so on that explain their lower employment probability more than religion itself.

Model $\mathrm{C}$ does not change much the previous conclusions on differences among religious denominations despite the addition of per capita social expenditure to quantify the possible impact on female labor supply decisions of the social services supplied in each country. We find that social expenditure is still statistically significant. It partly explains the religious gap, suggesting that there is some correlation between each religion and the model of welfare regime existing in the country. 
Model $D$ incorporates controls for different European regimes of welfare state, in order to capture institutional characteristics that may influence women' decision to work, other than religion. Still, per capita social expenditure is statistically significant. As expected, all welfare regimes, but the former socialist ones, show a lower than average probability of female employment than the Scandinavian one, which is in the baseline. As well known, in fact, Scandinavian countries typically exhibit an enviably high degree of gender equality. The former Socialist countries have a now long tradition of gender equality, which might explain why there women experience greater employment chances that in the Scandinavian countries (for a reconstruction of the literature on the outcomes of transition from plan to market on the gender wage gap, see, among others, Brainerd 2000; Pastore and Verashchagina 2011, and the references therein).

Also taking into account welfare state regimes variables does not dramatically change the results about religious affiliation: Orthodox and Muslim women present a higher than average risk to be unemployed / inactive with respect to the agnostics, while for Protestant women there is always a higher probability to be employed. The only difference is in the intensity of the association, which is slightly lower in this specification of the model.

The greatest effect of policy regimes variables is found in the case of Muslim women whose chances of finding a job are almost double those without controls: considering the impact of policy variables the probability of a Muslim woman to find employment reduces to just $33 \%$ less than average. For the Orthodox women, the effect is reduced by much less, to about $38 \%$. The effect of belonging to the Protestant religion is reduced down by about $20 \%$. For Catholic women, there is only a small impact.

Model E suggests that the impact of religious differences are robust to controls for country fixed effects in the case of the Muslim and Protestant religion, but not the Orthodox religion, whose coefficient becomes statistically insignificant. In other words, there seems to be a specificity in the Muslim and Protestant religions impact on female labor supply that is not captured by other cultural and policy country specificities. In the extreme view that considers as "religion specific" only the factors that go beyond other confounding factors, this is in our data the most important sign of the role of religion.

Overall, these findings confirm those of previous research according to which the impact of religious denominations on female participation is robust to the inclusion of controls for different welfare regimes and, in some cases, also national specificities, although the religious 
influence on the labor market behavior of women seems to reduce as a consequence of controlling for other national and cultural specificities.

\section{[Table 3 about here]}

\subsection{Religiosity and secularization}

Table 4 focuses on the effect of religiosity on female labor force participation. Control variables are the same as in Table 3. For each religious affiliation we consider two groups of individuals: the religiously active and the non-active. Religiosity is measured in this case with the intensity of religious services attendance: in fact, are considered to be religiously active those women who attend religious services more than or at least once a week. Comparison of model B of Table 3 and 4 shows some interesting results. First, Catholic women turn again to exhibit a lower than average employment probability. The estimate suggests that the overall (unconditional) impact of religion on female participation is essentially due to those individuals who live more actively their religiosity. The non-employment risk of religiously active Catholic women is statistically higher than average by $22 \%$ in Model B and slightly less in Model C and D. The coefficient becomes again not statistically significant in Model $E$, once controlling for country fixed effects, like in the Orthodox case. Catholic women who do not live actively their religion have the same employment chances as the baseline group of agnostic women. This finding can be taken as evidence confirming that a process of secularization has taken place among Catholic women.

Differences among religiously active and non-active women can be found also for other religious denominations, though such differences are less marked and of different nature. Muslim and Orthodox women are confirmed to have a higher than average risk to be jobless, and a higher level of religiosity increases the risk to remain jobless. Nonetheless, the impact of the Orthodox and Muslim religion is statistically significant also among the non-active religious women. In the case of Protestant women, living actively their religiosity tends to slightly reduce the employment chances, but not in a statistically significant way. Not religiously active Protestant women have higher than average probability to be employed. It's this component that explains the positive coefficient found in Table 3 for Protestant women.

In general, country fixed effects reduce to statistical insignificance the difference from the baseline of Catholic and Orthodox women, suggesting that some country differences might explain the different labor market behavior of women belonging to these groups.

[Table 4 about here] 
Table 5 is based on a different measure of religiosity, namely the answer to the question whether the respondent feels to be a religious person, beyond his declared affiliation to a given denomination. One would expect this definition to generate little differences in the coefficients of the estimates. However, this is the case only for the Protestant and Muslim women. The greatest difference is found in the case of the Orthodox. The religiously active have a lower than average employment probability, whereas the religiously non-active have higher than average employment probability. No difference is found for Catholic women or the other religions

\section{[Table 5 about here]}

\subsection{Migration, religion and assimilation}

Unreported estimates of the type presented in Table 3 and 4 have been run separately for native and immigrant women ${ }^{4}$. In the case of native women, there are essentially no remarkable differences from the overall sample. This is not surprising considering that they are the large majority of the sample. European countries still feature a low proportion of immigrants, about $9.5 \%$ in our data.

Among the immigrants, interestingly, the Orthodox women do not seem to be statistically different from the baseline of agnostic women anymore. This can be taken as evidence of the fact that immigrant women of Orthodox religion tend to assimilate easily with the employment characteristics of the host country. Protestant women continue to have a risk of joblessness smaller than the baseline, by about two times, in all specifications. Muslim women confirm to have a greater risk of joblessness, also when migrating, although the coefficient becomes not statistically significant when we control for welfare state regimes of the host country and for country fixed effects. This may be taken as some evidence of their assimilation or of the fact that they are in some way affected by the welfare state regime of the host country.

When we take into account the degree of religiosity for immigrant women, we find again that only Protestant and Muslim women are statistically different from the agnostics. Again it is the group of non-active Protestant women who have higher than average employment probability. For the Muslim women, we find, interestingly, that the religiously active have a much lower than average employment probability, but also the religiously non-active have a lower than average employment probability.

\footnotetext{
${ }^{4}$ Estimates are available on request from the authors.
} 
Table 6 presents the same estimates as in Table 3, but interacts the religious affiliation with the migration status. For each religious denomination, we define whether the individual is a native, a first generation immigrant or a second generation immigrant. We attain some interesting findings. Strangely enough, second generation immigrant women with a Catholic affiliation tend to have a statistically significant lower employment probability. For some reason, religious dogmas re-emerge after one generation, the opposite to the process of assimilation. Native Protestant women should be held responsible for the higher than average probability of employment of Protestant women in general. When migrating, Protestant women probably assimilate to the habits of women in the host country and therefore have average employment probability. Native Muslim women tend to have almost identical(-ly low) employment probabilities than first generation immigrant ones. Second generation Muslim women tend, instead, to exhibit an employment probability that although still lower than that of the omitted category of the agnostics, loses in statistical significance. In fact, when controlling for per capita social expenditure and the type of welfare state regime, Muslim women of second immigration tend to have an employment probability not statistically different from the baseline, probably as a consequence of the assimilation process. The Orthodox women tend to assimilate when migrating already when they are first generation immigrants, although, similar to the Catholic women, they tend to follow again religious beliefs when they are second generation immigrants.

Women belonging to other religious affiliations behave quite strangely: the first generation immigrants have lower than average probability, whereas the second generation immigrant have a much higher than average employment probably. This finding could be also due to the fact of catching the very specific behavior of some small group of migrants (see Table A1 in the Annex).

[Table 6 about here]

\section{Concluding Remarks}

This paper has attempted to empirically assess the common belief, neglected in the economic literature, according to which religious affiliations may possibly affect female labor market participation. We present several types of participation equations of women belonging to 47 different countries of the European continent where the European Values Study databank has been collected in 2008. We control not only for individual and household 
heterogeneity of women - education attainment, civil status, having children, presence of parents and grand-parents in the household, migration status, family educational background -, but also for such characteristics as making their living out of an income that is below the poverty line, having own parents and / or partners of a different nationality, living their religious feeling with a different intensity. We also control for the role of policy variables, here represented by the amount of per capita social expenditure and the fact of belonging to one of nine different welfare regimes. In our final estimate we control for country fixed effects.

Our enquiry finds strong evidence of the role that the beliefs of some religious denominations exert on the labor supply decisions of women. Women belonging to the Orthodox and, even more, Muslim denominations present a higher risk of non-employment than the agnostics. The impact is the greatest among the Muslim believers. In the estimates that control for the type of welfare regime adopted in the country, the Orthodox and Muslim women have a probability of employment between about 30 and $40 \%$ lower than average. Conversely and interestingly, belonging to the Protestant church increases the probability for a woman to be employed by about $50 \%$ with respect to the average.

The findings relative to the Muslim and Protestant religions hold also after controlling for country fixed effects, which confirms the importance of these types of religious denominations as factors able to importantly affect female labor supply.

Other religions, such as the Catholic, Evangelical and others are not statistically significant in conditional terms, although they are statistically significant in unconditional LOGIT estimates. It suggests that the negative unconditional correlation found between the share of women with a Catholic affiliation and the employment probability depend in fact on individual and household heterogeneity of Catholic women.

There are non-trivial differences between religiously active and non-active women. The greatest part of the religious effect is due to the groups that live their religious beliefs more intensively. When distinguishing between women who attend religious services at least once or more per week, we find that the Catholic women who are more active in their religious life have a statistically lower than average probability to work. In the case of Protestant women, instead, the positive impact on female participation depends essentially on the role of women who do not live much intensively their religious feelings. Protestant women who live actively their religions tend to have a higher than average probability of joblessness, although differences are not statistically significant. In the case of the women who belong to the Orthodox and Muslim denominations, we find little differences in the risk of joblessness 
between the religiously active and non-active women. These results are robust to the use of different sets of control variables, although the coefficient of Orthodox women turns not statistically significant when controlling for country fixed effects. 


\section{References}

Algan Y. and P. Cahuc, (2006), "Job protection: the Macho hypothesis", Oxford Review of Economic Policy, 22(3): 390-410.

Antecol, H., (2003), "Why is there cross-country variation in female labor force participation rates? The role of male attitudes toward family and sex roles", Claremont McKenna

College Working Paper No. http://www.claremontmckenna.edu/berger/pdf/sexroles.pdf.

Bettio F. and P. Villa, (1998), "A Mediterranean perspective on the breakdown of the relationship between participation and fertility", Cambridge Journal of Economics, 22(2): 137-171.

Blau, F. and L. Kahn (2012), "Substitution between Individual and Source Country Characteristics: Social Capital, Culture, and US Labor Market Outcomes among Immigrant Women", Cornell University, August 2012.

Brainerd, E. (2000). 'Women in Transition: Change in Gender Wage Differentials in Eastern Europe and FSU', Industrial and Labor Relations Review, 54(1), pp. 139-162.

Contreras D. and G. Plaza, (2010), "Cultural Factors in Women's Labor Force Participation in Chile", Feminist Economics, 16(2): 27-46.

Esping-Andersen G., (1990), The Three Worlds of Welfare Capitalism, Cambridge: Polity Press

Fernández R. and A. Fogli (2009) "Culture: An Empirical Investigation of Beliefs, Work, and Fertility", American Economic Journal: Macroeconomics, American Economic Association, 1(1): 146-77

Fortin N.M., (2005), "Gender Role Attitudes and Women's Labour Market Outcomes across OECD countries", Oxford Review of Economic Policy, 21 (3): 416-438.

Gomilschak, M., Haller, M., Höllinger, F., (2000), "Weibliche Erwerbstätigkeit und Einstellungen zur Rolle von Frauen", Österreichische Zeitschrift für Soziologie, 25(3): 65-78.

Guiso L., P. Sapienza and L. Zingales, (2003), “People's opium? Religion and economic attitudes", Journal of Monetary Economics, 50(1): 225-282.

H'madoun M., (2010), "Religion and labor force participation of women", Working Papers University of Antwerp, http://www.aiel.it/bacheca/PESCARA/papers/Hmadoun.pdf

Heineck, G., (2004), "Does religion influence the labour supply of married women in Germany?", Journal of Socio-Economics, 33(3): 307-328.

lannaccone, L.R., (1998), "Introduction to the economics of religion", Journal of Economic Literature, 36(3): 1465-1495.

Inglehart, R. and P. Norris, (2003), Rising Tide: Gender Equality and Cultural Change Around the World, Cambridge University Press.

Knudsen, K., Waerness, K., (1999), "Reactions to global processes of change: Attitudes toward gender roles and marriage in modern nations", Comparative Social Research, 18: 161195. 
Knudsen, K., Waerness, K., (2001), "National context, individual characteristics and attitudes on mothers' employment: A comparative analysis of Great Britain, Sweden and Norway", Acta Sociologica, 44(1): 67-79.

Lehrer E.L., (1995), "The Effects of Religion on the Labor Supply of Married Women" SocialScience Research 24(3): 281-301

Maneschiold P and B. Haraldsonn, (2007), "Religious Norms and Labour Supply of Married Women in Sweden", Finnish Economic Papers, 20(1): 41-56.

Pastore, F. and A. Verashchagina (2011), "When Does Transition Increase the Gender Wage Gap? An Application to Belarus", The Economics of Transition, 19(2): 333-369

Seguino S., (2007), "Plus ça Change? Evidence on Global Trends in Gender Norms and Stereotypes", Feminist Economics, 13(2): 1-28.

Simonazzi A., (2008), "Care regimes and national employment models", Cambridge Journal of Economics, 33 (2): 211-232.

Sjöberg, O., (2004), "The role of family policy institutions in explaining gender-role attitudes: a comparative multilevel analysis of thirteen industrialized countries", Journal of European Social Policy 14(2): 107-123. 


\section{Appendix of Tables and Figures}

Tables

Table 1: Shares of employed / non-employed women by religious affiliation

\begin{tabular}{|c|c|c|c|c|c|c|}
\hline & \multicolumn{2}{|l|}{ All } & \multicolumn{2}{|c|}{ Men } & \multicolumn{2}{|c|}{ Women } \\
\hline & $\begin{array}{l}\text { Non- } \\
\text { employed }\end{array}$ & Employed & $\begin{array}{l}\text { Non- } \\
\text { employed }\end{array}$ & Employed & $\begin{array}{l}\text { Non- } \\
\text { employed }\end{array}$ & Employed \\
\hline Roman Catholic & 3,346 & 8,008 & 973 & 3,832 & 2,373 & 4,176 \\
\hline in $\%$ & 29.47 & 70.53 & 20.25 & 79.75 & 36.23 & 63.77 \\
\hline Protestant & 751 & 3,548 & 281 & 1,651 & 470 & 1,897 \\
\hline in $\%$ & 17.47 & 82.53 & 14.54 & 85.46 & 19.86 & 80.14 \\
\hline $\begin{array}{l}\text { Free church / non- } \\
\text { conformist, Evangelical }\end{array}$ & 31 & 132 & 6 & 68 & 25 & 64 \\
\hline in $\%$ & 19.02 & 80.98 & 8.11 & 91.89 & 28.09 & 71.91 \\
\hline Jewish & 18 & 21 & 6 & 7 & 12 & 14 \\
\hline in $\%$ & 46.15 & 53.85 & 46.15 & 53.85 & 46.15 & 53.85 \\
\hline Muslim & 3,533 & 2,863 & 1,304 & 1,802 & 2,229 & 1,061 \\
\hline in $\%$ & 55.24 & 44.76 & 41.98 & 58.02 & 67.75 & 32.25 \\
\hline Hindu & 11 & 15 & 2 & 9 & 9 & 6 \\
\hline in $\%$ & 42.31 & 57.69 & 18.18 & 81.82 & 60 & 40 \\
\hline Buddhist & 9 & 25 & 3 & 14 & 6 & 11 \\
\hline in $\%$ & 26.47 & 73.53 & 17.65 & 82.35 & 35.29 & 64.71 \\
\hline Orthodox & 4,269 & 6,337 & 1,419 & 2,981 & 2,850 & 3,356 \\
\hline in $\%$ & 40.25 & 59.75 & 32.25 & 67.75 & 45.92 & 54.08 \\
\hline Other & 261 & 498 & 86 & 229 & 175 & 269 \\
\hline in $\%$ & 34.39 & 65.61 & 27.3 & 72.7 & 39.41 & 60.59 \\
\hline Total & 12,229 & 21,447 & 4,080 & 10,593 & 8,149 & 10,854 \\
\hline in $\%$ & 36.31 & 63.69 & 27.81 & 72.19 & 42.88 & 57.12 \\
\hline Agnostics & 3,305 & 8,175 & 1,356 & 4,349 & 1,949 & 3,826 \\
\hline in $\%$ & 28.79 & 71.21 & 23.77 & 76.23 & 33.75 & 66.25 \\
\hline
\end{tabular}

Source: own elaboration on EVS data. 
Table 2. Unconditional LOGIT estimates of the religious gap in female labor supply (Odds ratios)

\begin{tabular}{ll}
\hline Variable & \\
\hline Religion (baseline: agnostic) & $0.7463^{* * *}$ \\
Catholic & $1.7116^{* * *}$ \\
Protestant & 1.0856 \\
Evangelical & $0.2019^{* * *}$ \\
Muslim & $0.4994^{* * *}$ \\
Orthodox & $0.6298^{* * *}$ \\
Other religion & $0.7658^{* * *}$ \\
Atheists & $2.3581^{* * *}$ \\
Constant & 25035 \\
Number of observations & \\
\hline
\end{tabular}

Source: own elaboration on EVS data. 
Table 3: LOGIT estimates of the determinants of the employment status of women aged between 18 and 60 years (Odds ratios)

\begin{tabular}{|c|c|c|c|c|c|}
\hline Variable & Model A & Model B & Model C & Model D & Model E \\
\hline Age & $1.4556 * * *$ & $1.4565^{* * *}$ & $1.4584^{* * *}$ & $1.4668 * * *$ & $1.4908 * * *$ \\
\hline Age squared & $0.9961 * * *$ & $0.9960 * * *$ & $0.9960 * * *$ & $0.9959 * * *$ & $0.9957 * * *$ \\
\hline \multicolumn{6}{|l|}{$\begin{array}{l}\text { Education (baseline: primary education or } \\
\text { below) }\end{array}$} \\
\hline Low secondary (compulsory) & $1.6191 * * *$ & $1.3240^{* * *}$ & $1.3477 * * *$ & 1.0831 & 1.1507 \\
\hline High secondary & $2.5699 * * *$ & $2.1534 * * *$ & $2.1929 * * *$ & $1.8570 * * *$ & $2.0257 * * *$ \\
\hline Post-secondary & $3.8627 * * *$ & $3.1838 * * *$ & $3.2599 * * *$ & $2.5391 * * *$ & $3.1108 * * *$ \\
\hline Tertiary & $6.3942 * * *$ & $5.3669 * * *$ & $5.4642 * * *$ & $4.5483^{* * *}$ & $5.1970 * * *$ \\
\hline \multicolumn{6}{|l|}{ Civil status (baseline: married) } \\
\hline Single & $1.0774 * *$ & $1.0597 *$ & 1.0471 & 1.0444 & 1.0007 \\
\hline Number of children & $0.7577 * * *$ & $0.7596 * * *$ & $0.7606^{* * *}$ & $0.7511 * * *$ & $0.7592 * * *$ \\
\hline $\begin{array}{l}\text { Presence of a first child under the age of } \\
10 \text { years }\end{array}$ & $0.7510^{* * *}$ & $0.7438 * * *$ & $0.7402^{* * *}$ & $0.7174 * * *$ & $0.6978 * * *$ \\
\hline Parents are co-resident & $1.4898 * * *$ & $1.4236^{* * *}$ & $1.3940 * * *$ & $1.4265 * * *$ & $1.2765 * * *$ \\
\hline Grandparents are co-resident & 1.0877 & 1.0121 & $1.3940 * * *$ & 1.0966 & $1.1980 *$ \\
\hline Women living below the poverty line & $0.4758 * * *$ & $0.4724 * * *$ & $0.4867 * * *$ & $0.4726 * * *$ & $0.5433 * * *$ \\
\hline \multicolumn{6}{|l|}{ Migration status (baseline: native) } \\
\hline Immigrant of first generation & $0.7453 * *$ & $0.7833 *$ & $0.7759 *$ & 0.8131 & $0.7862 *$ \\
\hline Immigrant of second generation & 0.7894 & 0.846 & 0.8293 & 0.8445 & 0.8781 \\
\hline Father immigrant & 1.0203 & 1.0648 & 1.0421 & 1.0539 & 0.9372 \\
\hline Mother immigrant & 1.0847 & 1.121 & 1.1035 & 1.1268 & 1.0872 \\
\hline Foreign partner & 1.0344 & 1.1248 & 1.091 & 1.0703 & 1.008 \\
\hline \multicolumn{6}{|l|}{$\begin{array}{l}\text { Educational background (baseline: } \\
\text { parents have primary education or below) }\end{array}$} \\
\hline Parents with low secondary education & $1.4275^{* * *}$ & $1.3188^{* * *}$ & $1.3440 * * *$ & $1.2750 * * *$ & $1.2413^{* * *}$ \\
\hline Parents with high secondary education & $1.4155^{* * *}$ & $1.2763^{* * *}$ & $1.3079 * * *$ & $1.2707 * * *$ & $1.3565^{* * *}$ \\
\hline Parents with post-secondary education & $1.2703^{* *}$ & 1.1759 & $1.2047 *$ & 1.0517 & 1.13 \\
\hline Parents with tertiary education & $1.1387^{*}$ & 1.0526 & 1.0779 & 0.9863 & 1.0159 \\
\hline Population size of the place of residence & $1.0000^{*}$ & $1.0000^{*}$ & 1 & 1 & 1 \\
\hline Per capita social expenditure & $1.0069 * * *$ & & $1.0030^{* * *}$ & $1.0038 * * *$ & 1.0034 \\
\hline \multicolumn{6}{|l|}{ Religion (baseline: agnostic) } \\
\hline Catholic & & 0.9428 & 0.9645 & 0.9197 & 1.0116 \\
\hline Protestant & & $1.5881^{* * *}$ & $1.5468 * * *$ & $1.3658 * *$ & $1.2607^{*}$ \\
\hline Evangelical & & 0.8375 & 0.7518 & 0.7547 & 0.6216 \\
\hline Muslim & & $0.3811^{* * *}$ & $0.4428 * * *$ & $0.6706 * * *$ & $0.7327 * *$ \\
\hline Orthodox & & $0.6008^{* * *}$ & $0.6759 * * *$ & $0.6261^{* * *}$ & 0.9747 \\
\hline Other religion & & 0.816 & 0.8804 & 0.8097 & 0.9349 \\
\hline Atheists & & 0.9694 & 1.0386 & 1.0105 & 0.9603 \\
\hline \multicolumn{6}{|l|}{ Welfare regimes (baseline: Scandinavian) } \\
\hline Mediterranean countries & & & & $0.8421^{*}$ & \\
\hline Centre European countries & & & & $0.6458 * * *$ & \\
\hline Anglo-Saxon countries & & & & 0.8712 & \\
\hline $\begin{array}{l}\text { East European countries, entered in } \\
2004\end{array}$ & & & & $1.1820^{*}$ & \\
\hline
\end{tabular}




\begin{tabular}{|c|c|c|c|c|c|}
\hline $\begin{array}{l}\text { East European countries entered after } \\
2004\end{array}$ & & & & $1.4826^{* * *}$ & \\
\hline Former Soviet Union republics & & & & 0.996 & \\
\hline Former Yugoslavian countries & & & & $0.6226 * * *$ & \\
\hline Turkey & & & & $0.8421 *$ & \\
\hline Country dummies & & & & & yes \\
\hline Constant & $0.0001^{* * *}$ & $0.0002^{* * *}$ & $0.0002 * * *$ & $0.0002^{* * *}$ & $0.0001 * * *$ \\
\hline Number of observations & 22284 & 22284 & 22284 & 22284 & 22284 \\
\hline
\end{tabular}

Notes: *significant at $10 \% ;{ }^{* *}$ significant at5\%; *** significant at $1 \%$.

The figures in the Table represent odds ratios. The odds ratio associated to a characteristic $j$ is the relative risk of female participation for individuals with a given characteristics in the reference group. E.g., if the estimated odds ratio equals 1.5, the woman with a characteristics $j$ have a 50\% higher probability of participating to the labor market than the reference group; if the odds ratio equals 0.5 the individual with characteristics $j$ have $50 \%$ lower probability of participating to the labor market than the reference group.

Source: own elaboration on EVS data. 
Table 4: Active / non-active religious participation. Attendance of religious services. LOGIT estimates (Odds ratios)

\begin{tabular}{|c|c|c|c|c|c|}
\hline Variable & Model A & Model B & Model C & Model D & Model E \\
\hline \multicolumn{6}{|l|}{ Religion (baseline: agnostic) } \\
\hline Catholic active & & $0.7821 * *$ & $0.8191^{*}$ & $0.7302 * * *$ & 0.9422 \\
\hline Catholic non-active & & 1.0144 & 1.0257 & 0.993 & 1.0257 \\
\hline Protestant active & & 0.8511 & 0.8802 & 0.7643 & 0.7487 \\
\hline Protestant non-active & & $1.6993 * * *$ & $1.6497 * * *$ & $1.4779 * * *$ & $1.3721^{* *}$ \\
\hline Evangelical active & & 0.6914 & 0.6252 & 0.614 & 0.496 \\
\hline Evangelical non-active & & 1.005 & 0.9119 & 0.9114 & 0.7667 \\
\hline Muslim active & & $0.3218^{* * *}$ & $0.3686 * * *$ & $0.5327 * * *$ & $0.7032 *$ \\
\hline Muslim non-active & & $0.3901 * * *$ & $0.4482 * * *$ & $0.6857 * * *$ & $0.7320 * *$ \\
\hline Orthodox active & & $0.4563^{* * *}$ & $0.5062 * * *$ & $0.4547 * * *$ & 0.96 \\
\hline Orthodox non-active & & $0.6258^{* * *}$ & $0.6983 * * *$ & $0.6455 * * *$ & 0.9668 \\
\hline Other religion active & & 0.9253 & 0.9861 & 0.8654 & 0.9822 \\
\hline Other religion non-active & & 0.7563 & 0.8142 & 0.7633 & 0.8994 \\
\hline Atheists & & 0.9689 & 1.0324 & 0.9978 & 0.9563 \\
\hline
\end{tabular}

Notes: * ${ }^{*}$ ignificant at $10 \% ;{ }^{* *}$ significant at $5 \% ;{ }^{* * *}$ significant at $1 \%$.

Each model includes the same control variables as in Table 3.

Source: own elaboration on EVS data.

Table 5: Active / non-active religious participation. Feeling to be religious. LOGIT estimates (Odds ratios)

\begin{tabular}{|c|c|c|c|c|c|}
\hline Variable & Model A & Model B & Model C & Model D & Model E \\
\hline \multicolumn{6}{|l|}{ Religion (baseline: agnostic) } \\
\hline Catholic active & & 0.9984 & 0.9924 & $0.8144 * *$ & 0.9018 \\
\hline Catholic non-active & & 1.066 & 0.9963 & 0.8887 & 0.982 \\
\hline Protestant active & & $1.7793^{* * *}$ & $1.6677^{* * *}$ & $1.2907^{*}$ & 1.1573 \\
\hline Protestant non-active & & $1.5510 * * *$ & $1.4195^{* *}$ & 1.1322 & 1.0875 \\
\hline Evangelical active & & 0.9602 & 0.8059 & 0.7355 & 0.5803 \\
\hline Evangelical non-active & & 0.5035 & 0.4261 & 0.3933 & 0.4664 \\
\hline Muslim active & & $0.4184^{* * *}$ & $0.4778 * * *$ & $0.5780 * * *$ & $0.6398 * *$ \\
\hline Muslim non-active & & $0.4307 * *$ & $0.4860 * *$ & 0.8054 & 0.9575 \\
\hline Orthodox active & & $0.5958^{* * *}$ & $0.6580 * * *$ & $0.5280^{* * *}$ & $0.8560 *$ \\
\hline Orthodox non-active & & $1.2919^{*}$ & $1.4316^{* *}$ & 1.0798 & 1.0452 \\
\hline Other religion active & & 0.8747 & 0.9195 & $0.7271 *$ & 0.8357 \\
\hline Other religion non-active & & 1.0306 & 1.0617 & 0.8483 & 0.9678 \\
\hline Atheists & & 1.0504 & 1.0943 & 0.9228 & 0.8784 \\
\hline
\end{tabular}

Notes: *significant at $10 \% ;{ }^{* *}$ significant at $5 \%$; ** significant at $1 \%$.

Each model includes the same control variables as in Table 3.

Source: own elaboration on EVS data. 
Table 6: Religion and migration status. LOGIT estimates (Odds ratios)

\begin{tabular}{llllll}
\hline Variable & Model A & Model B & Model C & Model D & Model E \\
\hline Religion (baseline: agnostic) & & & & & \\
Native Catholic & 0.9841 & 0.9831 & 0.9343 & 0.9781 & 0.9841 \\
\hline Catholic 1st generation immigrant & 1.1159 & 1.1109 & 1.1149 & 1.1399 & 1.1159 \\
\hline Catholic 2nd generation immigrant & $0.5729^{*}$ & $0.5710^{*}$ & 0.5846 & 0.5998 & $0.5729^{*}$ \\
\hline Native Protestant & $1.6819^{* * *}$ & $1.5792^{* * *}$ & $1.3701^{* *}$ & $1.2289^{*}$ & $1.6819^{* * *}$ \\
\hline Protestant 1st generation immigrant & 1.6273 & 1.6678 & 1.5689 & 1.4181 & 1.6273 \\
\hline Protestant 2nd generation immigrant & 0.7083 & 0.7741 & 0.6547 & 0.6928 & 0.7083 \\
\hline Native Evangelical & 1.182 & 1.016 & 1.0416 & 0.7911 & 1.182 \\
\hline Evangelical 1st generation immigrant & 0.5172 & 0.4522 & 0.4258 & 0.3897 & 0.5172 \\
\hline Native Muslim & $0.3882^{* * *}$ & $0.4437^{* * *}$ & $0.6707^{* * *}$ & $0.7077^{* * *}$ & $0.3882^{* * *}$ \\
\hline Muslim 1st generation immigrant & $0.4142^{* * *}$ & $0.4652^{* * *}$ & 0.6736 & $0.5462^{* *}$ & $0.4142^{* * *}$ \\
\hline Muslim 2nd generation immigrant & $0.4497^{*}$ & 0.514 & 0.8529 & 0.7373 & $0.4497^{*}$ \\
\hline Native Orthodox & $0.6071^{* * *}$ & $0.6653^{* * *}$ & $0.6132^{* * *}$ & 0.9291 & $0.6071^{* * *}$ \\
\hline Orthodox 1st generation immigrant & 0.882 & 0.9986 & 0.9272 & 1.0864 & 0.882 \\
Orthodox 2 ${ }^{\text {nd }}$ generation immigrant & $0.4501^{* *}$ & $0.5391^{*}$ & $0.4888^{*}$ & 0.6084 & $0.4501^{* *}$ \\
\hline Native of other religion & 0.6105 & $0.5986^{*}$ & $0.6044^{*}$ & 0.6587 & 0.6105 \\
\hline Other religion 1st generation immigrant & $0.0967^{*}$ & $0.1007^{*}$ & $0.1172^{*}$ & $0.1122^{*}$ & $0.0967^{*}$ \\
\hline Other religion 2nd generation immigrant & $13.2892^{*}$ & $13.6161^{* *}$ & $10.6341^{*}$ & $11.3391^{*}$ & $13.2892^{*}$ \\
\hline Atheists & 1.0165 & 1.0641 & 1.0385 & 0.9308 & 1.0165 \\
\hline
\end{tabular}

Notes: *significant at $10 \% ;{ }^{* *}$ significant at $5 \% ; * * *$ significant at $1 \%$.

Each model includes the same control variables as in Table 3.

Source: own elaboration on EVS data. 
Figures

Figure 1: Female employment rate and share of individuals in the population belonging to the catholic and orthodox denominations in 2008

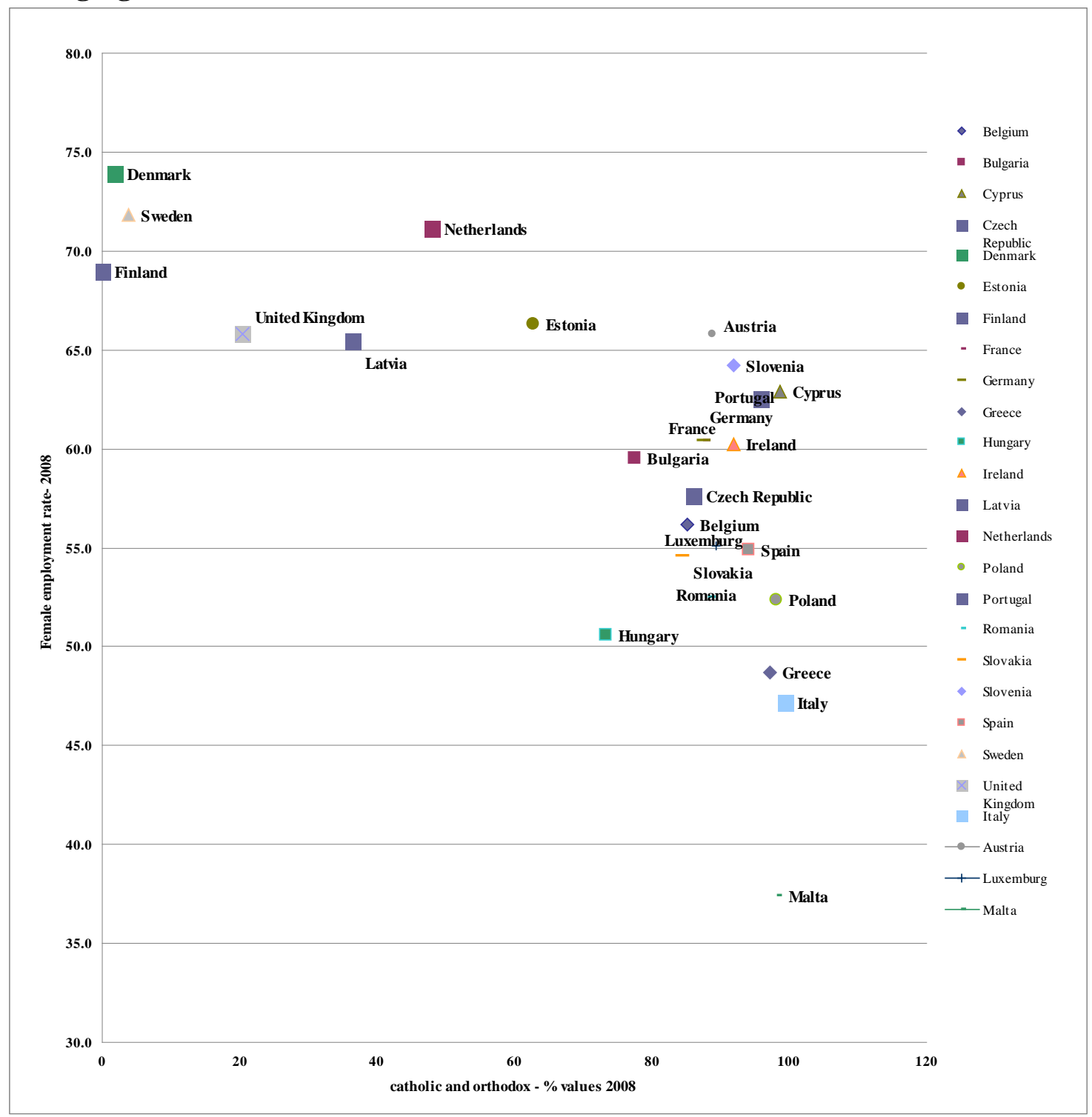

Note: in the case of Romania, Bulgaria, Cyprus, Greece and Estonia, the share of individuals belonging to the orthodox denomination is considered.

Source: our elaboration on Eurostat (female participation) and EVS data. 
Figure 2. Relative disadvantage of women in terms of employment rates by religion

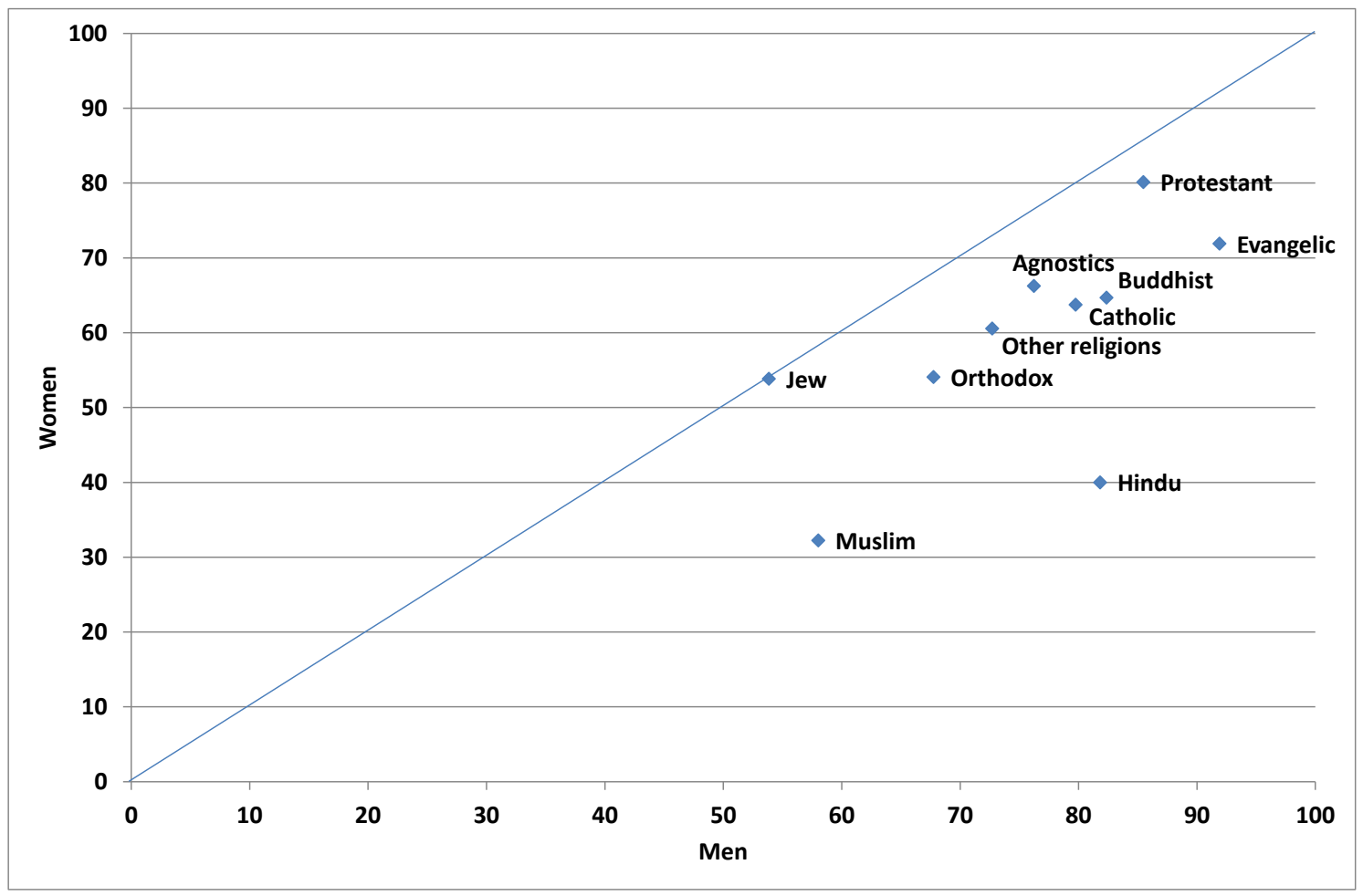

Source: own elaboration on EVS data. 


\section{Annex}

Table A1. Variables' definition

\begin{tabular}{|c|c|c|}
\hline Variables & Variable name & Definition \\
\hline \multicolumn{3}{|l|}{ Dependent variables } \\
\hline $\begin{array}{l}\text { Employment status } \\
\text { (employed, not } \\
\text { employed) }\end{array}$ & Employed_not employed & $\begin{array}{l}=1 \text { if wage employee (full-time or part-time) or self- } \\
\text { employed; }=0 \text { otherwise }\end{array}$ \\
\hline $\begin{array}{l}\text { Employment status } \\
\text { (employed, inactive) }\end{array}$ & Employed_inactive & $\begin{array}{l}=1 \text { if wage employee (full-time or part-time) or self- } \\
\text { employed; }=2 \text { if inactive; }=3 \text { if unemployed }\end{array}$ \\
\hline \multicolumn{3}{|c|}{ Independent variables of which: } \\
\hline \multicolumn{3}{|c|}{ Individual characteristics } \\
\hline Age & Age & Number of years $=2012-$ year of birth (v303) \\
\hline Level of education & Compulsory_school & $=1$, if compulsory school; $=0$, otherwise \\
\hline Level of education & Low Secondary & $=1$, if Low secondary; $=0$, otherwise \\
\hline Level of education & High Secondary & $=1$, if Second stage of secondary school; $=0$, otherwise \\
\hline Level of education & Post-Secondary & $\begin{array}{l}=1 \text {, if post- secondary non- tertiary education; }=0 \text {, } \\
\text { otherwise }\end{array}$ \\
\hline Level of education & Tertiary & $\begin{array}{l}=1 \text {, if first or second stage of tertiary education; }=0 \text {, } \\
\text { otherwise }\end{array}$ \\
\hline Civil status & Legal status & $=1$, if married or registered partnership; $=0$, otherwise \\
\hline \multicolumn{3}{|c|}{ Household characteristics } \\
\hline Co-resident parents & cores_par & $=1$, if parents are co-resident; $=0$, otherwise \\
\hline Co-resident grandparents & cores_grpa & $\begin{array}{l}=1 \text {, if grandparents are co-resident; }=0 \text {, otherwise } \\
=1 \text {, if the household income is under poverty threshold; }=0 \\
\text { otherwise }\end{array}$ \\
\hline Poverty threshold & poors_Az1 & $\begin{array}{l}\text { Note that the variable has been calculated starting from } \\
\text { the Stata commands "poverty", which computes the } \\
\text { poverty line as two-third of the median income, in this } \\
\text { case the household income. }\end{array}$ \\
\hline Number of children & n_children & Number of children \\
\hline $\begin{array}{l}\text { Presence of a first child } \\
\text { under the age of } 10 \text { years }\end{array}$ & Child_minore10 & $=1$ if first child under the age of 10 years; $0=$ otherwise \\
\hline $\begin{array}{l}\text { Level education father or } \\
\text { mother- pre-primary } \\
\text { primary }\end{array}$ & classe1 & $=1$, if compulsory school; $=0$, otherwise \\
\hline $\begin{array}{l}\text { Level education father or } \\
\text { mother- lower secondary }\end{array}$ & classe2 & $=1$, Lower secondary $=0$, otherwise \\
\hline $\begin{array}{l}\text { Level education father or } \\
\text { mother- secondary } \\
\text { Level education father or }\end{array}$ & classe3 & $=1$, secondary $=0$, otherwise \\
\hline $\begin{array}{l}\text { mother- post secondary } \\
\text { non tertiary }\end{array}$ & classe4 & $=1$, post-secondary non tertiary $=0$, otherwise \\
\hline $\begin{array}{l}\text { Level education father or } \\
\text { mother- first and second } \\
\text { stage tertiary }\end{array}$ & classe5 & $\begin{array}{l}=1 \text {, first or second stage of tertiary education } 0=\text {, } \\
\text { otherwise }\end{array}$ \\
\hline
\end{tabular}

\begin{tabular}{|c|c|c|}
\hline \multicolumn{3}{|l|}{ Migration status } \\
\hline Years of immigration & anni_immigr & $\begin{array}{l}\text { Years from which the interviewed lives in the country where } \\
\text { he resides }\end{array}$ \\
\hline Nationality & national & $=1$ if interviewed has country nationality; $0=$ otherwise \\
\hline Parents are immigrants & par_immig & $=1$ if one or both parents are immigrants; $0=$ otherwise \\
\hline Father is immigrant & father_immig & $=1$ if the father is immigrant; $0=$ otherwise \\
\hline Mother is immigrant & mother_immig & $=1$ if the mother is immigrant; $0=$ otherwise \\
\hline Partner is immigrant & foreign_partner & $=1$ if partner has foreign nationality \\
\hline \multicolumn{3}{|c|}{ Societal characteristics } \\
\hline $\begin{array}{l}\text { Population size of the city } \\
\text { of residence }\end{array}$ & pop_res & $\begin{array}{l}=1, \ldots 8 \text { according to dimension of population in the city of } \\
\text { residence ( } 8 \text { class sizes from less than } 2000 \text { inhabitants to }\end{array}$ \\
\hline
\end{tabular}




\begin{tabular}{|c|c|c|}
\hline & & more than half a million), as based on question v370. \\
\hline \multicolumn{3}{|l|}{ Religious beliefs } \\
\hline Catholic affiliation & Catholic & $=1$ if Catholic; $=0$ otherwise \\
\hline Protestant affiliation & Protestant & $=1$ if Protestant; $=0$ otherwise \\
\hline Evangelical affiliation & Evangelical & $=1$ if Evangelical; $=0$ otherwise \\
\hline Muslim affiliation & Muslim & $=1$ if Muslim; $=0$ otherwise \\
\hline Orthodox affiliation & Orthodox & $=1$ if Orthodox; $=0$ otherwise \\
\hline Other Religious affiliation & Religion_other & $=1$ if Jew, Hindu, Buddhist or other religion; $=0$ otherwise \\
\hline Atheist & Atei & $\begin{array}{l}=1 \text { if now and in the past did not belong to any religious } \\
\text { affiliation; }=0 \text { otherwise }\end{array}$ \\
\hline Agnostic & Agnostic & $=1$ if agnostic; $0=$ otherwise \\
\hline \multicolumn{3}{|l|}{ Degree of religiosity } \\
\hline Level of religiosity & Religiosity & $\begin{array}{l}=1 \text { if attending religious services more than once or once a } \\
\text { week; }=0 \text { otherwise }\end{array}$ \\
\hline Active catholic & catholic_active & $\begin{array}{l}=1 \text { if Catholic and attending religious services more than } \\
\text { once or at least once a week; }=0 \text { otherwise }\end{array}$ \\
\hline Non active catholic & catholic_nonactive & $\begin{array}{l}=1 \text { if Catholic and attending religious services less than } \\
\text { once a week; }=0 \text { otherwise }\end{array}$ \\
\hline Active protestant & protestant_active & $\begin{array}{l}=1 \text { if Protestant and attending religious services more than } \\
\text { once or at least once a week; }=0 \text { otherwise }\end{array}$ \\
\hline Non active protestant & protestant_nonactive & $\begin{array}{l}=1 \text { if Protestant and attending religious services less than } \\
\text { once a week; }=0 \text { otherwise }\end{array}$ \\
\hline Active evangelist & evangelic_active & $\begin{array}{l}=1 \text { if Evangelical and attending religious services more than } \\
\text { once or at least once a week; }=0 \text { otherwise }\end{array}$ \\
\hline Non active evangelist & evangelic_nonactive & $\begin{array}{l}=1 \text { if Evangelist and attending religious services less than } \\
\text { once a week; = } 0 \text { otherwise }\end{array}$ \\
\hline Active Muslim & muslim_active & $\begin{array}{l}=1 \text { if Muslim and attending religious services more than } \\
\text { once or at least once a week; }=0 \text { otherwise }\end{array}$ \\
\hline Non active Muslim & muslim_nonactive & $\begin{array}{l}=1 \text { if Muslim and attending religious services less than once } \\
\text { a week; }=0 \text { otherwise }\end{array}$ \\
\hline Active orthodox & orthodox_active & $\begin{array}{l}=1 \text { if Orthodox and attending religious services more than } \\
\text { once or at least once a week; }=0 \text { otherwise }\end{array}$ \\
\hline Non active orthodox & orthodox_nonactive & $\begin{array}{l}=1 \text { if } \text { Orthodox and attending religious services less than } \\
\text { once a week; }=0 \text { otherwise }\end{array}$ \\
\hline Active other religion & religion_other_active & $\begin{array}{l}=1 \text { if other religion and attending religious services more } \\
\text { than once or at least once a week; }=0 \text { otherwise }\end{array}$ \\
\hline Non active other religion & religion_other_nonactive & $\begin{array}{l}=1 \text { if other religion and attending religious services less } \\
\text { than once a week; }=0 \text { otherwise }\end{array}$ \\
\hline \multicolumn{3}{|l|}{ Religion and migration } \\
\hline Native Catholic & cattres & $=1$ if Catholic and resident; $=0$ otherwise \\
\hline $\begin{array}{l}\text { Catholic immigrant first } \\
\text { generation }\end{array}$ & cattimmigprima & $=1$ if Catholic and first generation immigrant; $=0$ otherwise \\
\hline $\begin{array}{l}\text { Catholic immigrant } \\
\text { second generation }\end{array}$ & cattimmigseconda & $\begin{array}{l}=1 \text { if Catholic and second generation immigrant; }=0 \\
\text { otherwise }\end{array}$ \\
\hline Native Protestant & protestantres & $=1$ if Protestant and resident; $=0$ otherwise \\
\hline $\begin{array}{l}\text { Protestant immigrant first } \\
\text { generation }\end{array}$ & protestantimmigprima & $\begin{array}{l}=1 \text { if Protestant and first generation immigrant; }=0 \\
\text { otherwise }\end{array}$ \\
\hline $\begin{array}{l}\text { Protestant immigrant } \\
\text { second generation }\end{array}$ & protestantimmigseconda & $\begin{array}{l}=1 \text { if Protestant and second generation immigrant; }=0 \\
\text { otherwise }\end{array}$ \\
\hline Native Evangelical & evangelicres & $=1$ if Evangelical and resident; $=0$ otherwise \\
\hline $\begin{array}{l}\text { Evangelical immigrant } \\
\text { first generation }\end{array}$ & evangelicimmigprima & $\begin{array}{l}=1 \text { if Evangelical and first generation immigrant; }=0 \\
\text { otherwise }\end{array}$ \\
\hline $\begin{array}{l}\text { Evangelical immigrant } \\
\text { second generation }\end{array}$ & evangelicimmigseconda & $\begin{array}{l}=1 \text { if Evangelical and second generation immigrant; =0 } \\
\text { otherwise }\end{array}$ \\
\hline Native Muslim & muslimres & $=1$ if Muslim and resident; $=0$ otherwise \\
\hline $\begin{array}{l}\text { Muslim immigrant first } \\
\text { generation } \\
\text { Muslim immigrant second } \\
\text { generation }\end{array}$ & muslimimmigseconda & $\begin{array}{l}=1 \text { if Muslim and first generation immigrant; }=0 \text { otherwise } \\
=1 \text { if Muslim and second generation immigrant; }=0 \\
\text { otherwise }\end{array}$ \\
\hline
\end{tabular}


Native Orthodox

Orthodox immigrant first

generation

Orthodox immigrant

second generation

Native of Other religion

Other religion immigrant

first generation

Other religion immigrant

second generation

\section{Welfare state regime}

Per capita social

expenditure

Mediterranean countries

Center European

countries

Scandinavian countries

Anglo-Saxon countries

East European countries, entered in 2004

East European countries entered after 2004

East European countries, ex-soviet republic

Ex Yugoslavian countries

Turkey

dum_turchia a

dum med

dum_scand

dum_anglo

$=1$ if Orthodox and resident; $=0$ otherwise

$=1$ if Orthodox and first generation immigrant; $=0$ otherwise

$=1$ if Orthodox and second generation immigrant; $=0$ otherwise

$=1$ if other religion and resident; $=0$ otherwise

$=1$ if other religion and first generation immigrant; $=0$ otherwise

religion_otherimmigsecond $=1$ if other religion and second generation immigrant; $=0$ otherwise

socialex_procapite

dum_centreu

dum_esteu_primi_entr

dum_esteu_second_entr

dum_esteu_exrep_soc_sov

2004; $=0$ otherwise

$=1$ if country is ex Yugoslavian; $=0$ otherwise

$=1$ if Turkey $=0$ otherwise
In thousands of euros (Eurostat data).

$=1$ if country belong to Mediterranean welfare regime; $=0$ otherwise

$=1$ if country belong to center European welfare regime; $=0$ otherwise

$=1$ if country belong to Scandinavian welfare regime; $=0$ otherwise

$=1$ if country belong to Anglo-Saxon welfare regime; =0 otherwise

$=1$ if country if part of East European countries, entered in EU in 2004; $=0$ otherwise

$=1$ if country if part of East European countries, entered in EU after 2004; $=0$ otherwise

$=1$ if country if part of ex Sovietic republic, entered in EU in

Table A2. Descriptive statistics

\begin{tabular}{|c|c|}
\hline Variables & \\
\hline Dependent variables & Mean / \% \\
\hline Employment status (employed, not employed) & 0.5925 \\
\hline Employment status (employed, inactive) & 1.5338 \\
\hline \multicolumn{2}{|l|}{ Independent variables of which: } \\
\hline \multicolumn{2}{|l|}{ Individual characteristics } \\
\hline Age & 40.9217 \\
\hline Education: Compulsory school & 0.0744 \\
\hline Education: Low secondary & 0.1453 \\
\hline Education: High secondary & 0.4395 \\
\hline Education: Post-secondary & 0.0646 \\
\hline Education: Tertiary & 0.2743 \\
\hline Civil status & 0.5695 \\
\hline \multicolumn{2}{|l|}{ Household characteristics } \\
\hline Co-resident parents & 1.7384 \\
\hline Co-resident grandparents & 1.9537 \\
\hline Poverty threshold & 0.3830 \\
\hline Number of children & 1.4011 \\
\hline Presence of a first child under the age of 10 years & 0.1155 \\
\hline Level education father or mother- pre-primary primary & 0.2438 \\
\hline Level education father or mother- lower secondary & 0.1792 \\
\hline Level education father or mother- secondary & 0.3144 \\
\hline Level education father or mother- post secondary non tertiary & 0.0429 \\
\hline Level education father or mother- first and second stage tertiary & 0.1474 \\
\hline \multicolumn{2}{|l|}{ Migration status } \\
\hline Years of immigration & 23.4436 \\
\hline Nationality & 0.9436 \\
\hline
\end{tabular}




\begin{tabular}{|c|c|}
\hline Parents are immigrants & 0.1405 \\
\hline Father is immigrant & 0.1128 \\
\hline Mother is immigrant & 0.1115 \\
\hline Partner is immigrant & 0.0500 \\
\hline \multicolumn{2}{|l|}{ Societal characteristics } \\
\hline Population size of the city of residence & 172657 \\
\hline Per capita social expenditure & 31.9693 \\
\hline \multicolumn{2}{|l|}{ Religious beliefs } \\
\hline Catholic affiliation & 0.2613 \\
\hline Protestant affiliation & 0.0950 \\
\hline Evangelic affiliation & 0.0036 \\
\hline Muslim affiliation & 0.1310 \\
\hline Orthodox affiliation & 0.2477 \\
\hline Other Religious affiliation & 0.0200 \\
\hline Atheist & 0.1744 \\
\hline Agnostic & 0.0636 \\
\hline \multicolumn{2}{|l|}{ Degree of religiosity } \\
\hline Level of religiosity & 0.1559 \\
\hline Active catholic & 0.0783 \\
\hline Non active catholic & 0.1830 \\
\hline Active protestant & 0.0074 \\
\hline Non active protestant & 0.0877 \\
\hline Active evangelist & 0.0015 \\
\hline Non active evangelist & 0.0021 \\
\hline Active muslim & 0.0191 \\
\hline Non active muslim & 0.1119 \\
\hline Active orthodox & 0.0361 \\
\hline Non active orthodox & 0.2116 \\
\hline Active other religion & 0.0072 \\
\hline Non active other religion & 0.0128 \\
\hline \multicolumn{2}{|l|}{ Religion and migration } \\
\hline Catholic native & 0.2230 \\
\hline Catholic immigrant first generation & 0.0213 \\
\hline Catholic immigrant second generation & 0.0048 \\
\hline Protestant native & 0.0842 \\
\hline Protestant immigrant first generation & 0.0048 \\
\hline Protestant immigrant second generation & 0.0008 \\
\hline Evangelic native & 0.0029 \\
\hline Evangelic immigrant first generation & 0.0004 \\
\hline Evangelic immigrant second generation & 0.0001 \\
\hline Muslim native & 0.1161 \\
\hline Muslim immigrant first generation & 0.0099 \\
\hline Muslim immigrant second generation & 0.0021 \\
\hline Orthodox native & 0.2073 \\
\hline Orthodox immigrant first generation & 0.0202 \\
\hline Orthodox immigrant second generation & 0.0056 \\
\hline Other religion native & 0.0140 \\
\hline Other religion immigrant first generation & 0.0035 \\
\hline Other religion immigrant second generation & 0.0006 \\
\hline
\end{tabular}

Source: own elaboration on EVS data. 
Table A3. Descriptive statistics by religious denomination

\begin{tabular}{|c|c|c|c|c|c|c|}
\hline Dependent variables & Catholic & Protestant & Evangelic & Muslim & Orthodox & Other \\
\hline & Mean / \% & Mean / \% & Mean / \% & Mean / \% & Mean / \% & Mean / \% \\
\hline $\begin{array}{l}\text { Employment status (employed, not } \\
\text { employed) }\end{array}$ & 0.6377 & 0.8014 & 0.7191 & 0.3225 & 0.5408 & 0.5976 \\
\hline $\begin{array}{l}\text { Employment status (employed, } \\
\text { inactive) }\end{array}$ & 1.4483 & 1.2594 & 1.2889 & 1.8577 & 1.6321 & 1.5241 \\
\hline \multicolumn{7}{|l|}{ Independent variables of which: } \\
\hline \multicolumn{7}{|l|}{ Individual characteristics } \\
\hline Age & 41.8151 & 43.1164 & 43.7556 & 38.0932 & 41.1385 & 40.8944 \\
\hline Civil status & 0.5830 & 0.5669 & 0.6889 & 0.6374 & 0.6128 & 0.5580 \\
\hline Education: Compulsory school & 0.0781 & 0.0093 & 0.0444 & 0.2706 & 0.0328 & 0.0823 \\
\hline Education: Low secondary & 0.1818 & 0.1527 & 0.2222 & 0.1471 & 0.0898 & 0.1767 \\
\hline Education: High secondary & 0.4403 & 0.3578 & 0.2111 & 0.3844 & 0.4750 & 0.3876 \\
\hline Education: Post-secondary & 0.0533 & 0.0797 & 0.1000 & 0.0190 & 0.1011 & 0.0663 \\
\hline Education: Tertiary & 0.2454 & 0.3974 & 0.4222 & 0.1776 & 0.2992 & 0.2849 \\
\hline \multicolumn{7}{|l|}{ Household characteristics } \\
\hline Co-resident parents & 1.7575 & 1.9130 & 1.9310 & 1.6592 & 1.6628 & 1.7895 \\
\hline Co-resident grandparents & 1.9689 & 1.9905 & 1.9885 & 1.8961 & 1.9402 & 1.9756 \\
\hline Poverty threshold & 0.3268 & 0.1935 & 0.0889 & 0.4270 & 0.5493 & 0.3944 \\
\hline Number of children & 1.4193 & 1.5965 & 1.9556 & 1.5769 & 1.3725 & 1.4527 \\
\hline $\begin{array}{l}\text { Presence of a first child under the } \\
\text { age of } 10 \text { years }\end{array}$ & 0.1058 & 0.1223 & 0.1444 & 0.1345 & 0.1091 & 0.1414 \\
\hline $\begin{array}{l}\text { Level education father or mother- } \\
\text { pre-primary primary }\end{array}$ & 0.3001 & 0.1401 & 0.2000 & 0.4593 & 0.1961 & 0.2771 \\
\hline $\begin{array}{l}\text { Level education father or mother- } \\
\text { lower secondary }\end{array}$ & 0.1961 & 0.2173 & 0.2444 & 0.1321 & 0.1552 & 0.1867 \\
\hline $\begin{array}{l}\text { Level education father or mother- } \\
\text { secondary }\end{array}$ & 0.2984 & 0.3287 & 0.2111 & 0.2073 & 0.3529 & 0.2430 \\
\hline $\begin{array}{l}\text { Level education father or mother- } \\
\text { post secondary non tertiary }\end{array}$ & 0.0236 & 0.0561 & 0.0556 & 0.0211 & 0.0791 & 0.0241 \\
\hline $\begin{array}{l}\text { Level education father or mother- } \\
\text { first and second stage tertiary }\end{array}$ & 0.1004 & 0.1764 & 0.2222 & 0.1385 & 0.1665 & 0.1687 \\
\hline \multicolumn{7}{|l|}{ Migration status } \\
\hline Years of immigration & 23.1041 & 23.5000 & 13.4000 & 20.2365 & 26.7809 & 17.6395 \\
\hline Nationality & 0.9429 & 0.9740 & 0.9333 & 0.9554 & 0.9372 & 0.8825 \\
\hline Parents are immigrants & 0.1260 & 0.0963 & 0.1778 & 0.1066 & 0.1489 & 0.2829 \\
\hline Father is immigrant & 0.1049 & 0.0691 & 0.1444 & 0.0960 & 0.1173 & 0.2251 \\
\hline Mother is immigrant & 0.0999 & 0.0683 & 0.1556 & 0.0978 & 0.1139 & 0.2430 \\
\hline Partner is immigrant & 0.0528 & 0.0327 & 0.0556 & 0.0562 & 0.0419 & 0.1096 \\
\hline \multicolumn{7}{|l|}{ Societal characteristics } \\
\hline $\begin{array}{l}\text { Population size of the city of } \\
\text { residence }\end{array}$ & 120410.2000 & 132389.6000 & 108471.4000 & 188010.6000 & 237404.7000 & 168537.7000 \\
\hline Per capita social expenditure & 48.5256 & 59.1683 & 74.9938 & 3.6623 & 11.0372 & 32.3483 \\
\hline
\end{tabular}

Source: own elaboration on EVS data. 